\title{
DIVERSITY OF SUBTERRANEAN TERMITES (BLATTODEA: TERMITOIDEA) ON VARIOUS TYPES HABITAT AROUND IPB UNIVERSITY CAMPUS, BOGOR, INDONESIA
}

\author{
Nadzirum Mubin, Idham Sakti Harahap, \& Giyanto \\ Department of Plant Protection, Faculty of Agriculture, IPB University, Indonesia \\ Jl. Kamper, Kampus IPB Dramaga, Bogor 16680 \\ E-mail: mubin.nadzirum@apps.ipb.ac.id
}

\begin{abstract}
Diversity of subterranean termites (Blattodea: Termitoidea) on various types habitat around IPB University Campus, Bogor, Indonesia. Termites are social insects that play an important role in ecosystem. Habitat is a crucial factors determining diversity of termites. IPB University campus has quite diverse habitat types. In this research, we study the diversity and abundance of termite species around IPB University campus. Two methods used for data collection, i.e. baiting system with pine wood and transect survey within $10 \times 10 \mathrm{~m}$ area. Six species of termites found belongs to two families, Termitidae (Macrotermes gilvus, Odontotermes javanicus, Microtermes insperatus, and Capritermes mohri) and Rhinotermitidae (Schedorhinotermes javanicus and Coptotermes curvignathus). The most diverse with the high abundance of these termites are found in the rubber trees area, Faculty of Fisheries (FPI) and the forest behind the main administration building, Rectorate (REK) because this area provides an abundant source of cellulose as a food source for termites. While the building areas tend to have a lower diversity and abundance index because food sources for termites are not always available due to human activities. Non-metric multidimensional scaling analysis shows that the termites species composition is different between study area.
\end{abstract}

Key words: abundance, diversity, Termitidae, Rhinotermitidae

\section{INTRODUCTION}

Termites (Blattodea: Termitoidea) are social insects that play an important role for nutrient cycle in nature. Wood can be consumed more rapid by termites than other organisms such as worms, fungi, and bacteria. Cellulose materials that have been weathered in nature require the role of termites as a decomposer to accelerate the rotation of the nutrient cycle in nature (Krishna, 1969; Freymann et al., 2008; Paul et al., 2018).

Forests are a natural habitat for decomposers such as termites. Termites diversity in forests is higher than in habitat types such as plantations (homogeneous trees) or urban areas (Bignell \& Eggleton, 2000). Plant species are more diverse in forest (heterogeneous) than those in plantations. Keng (2006) said that the diversity of termite species in primary forest ecosystems is higher than in cocoa plantations in Sabah, Malaysia.

In the plantation habitat, termites act as a pest as well. In the Araucaria and Acacia plantations (Acasia crassicarpa), the dominance of the Coptotermes attack was found (Jasmi \& Ahmad, 2011; Haneda et al., 2017). Oil palm plantations in Sarawak-Malaysia, the Rhinotermitidae family is found more than other termite families (Bong et al., 2012).

Survey of termite diversity conducted in residential or building areas in Jakarta were found four species termite i.e. Macrotermes gilvus, Microtermes insperatus, Capritermes mohri, and C. curvignathus (Lantera, 2014; Arinana et al., 2014; Arinana et al., 2016). From these cases, there are an interesting concern whether the change on ecological functions will affect the termite diversity. The diversity of termite is lower in urban area, but their status is change as an urban pest.

IPB in Dramaga is a campus with various type of habitats such as experimental station and buildings of residential areas. Information about the diversity and abundance of termites is not widely known. Therefore this research was conducted to study diversity and abundance of termites in IPB campus, especially whitin trees and buildings of residential area. 


\section{MATERIALS AND METHODS}

Research Site. Termite sampling was carried out at the IPB University campus-Bogor and then proceed with the identification process at the Insect Taxonomy Laboratory, Department of Plant Protection, Faculty of Agriculture, IPB.

Sampling and Termite Identification. Sampling was carried out in the trees and building areas (Table 1). Two methods are used in the sampling process, which are baiting and transect surveys. The baiting method is carried out at each sampling location using pine wood $(46 \times 2 \times 2 \mathrm{~cm})$ which is formed like a stick with the standard ASTM-D-1758-96-2008 (Figure 1)
(ASTM 2008; Arinana et al., 2014) and install on a predetermined plot. While the transect survey method was carried out within $10 \times 10 \mathrm{~m}$ area. Termites found from the field were collected and the location where they discovered was recorded. The identification process is carried out on the soldier caste because it has a character that is easier to distinguish compared to the workers caste. Termite identification is carried out to the species level based on Ahmad (1958) and Tho (1992).

Observation of Habitat Type. The location of termite found was recorded and documented to see the effect of habitat on termite diversity and distribution following Jones (2000); Jones et al. (2003); Deblauwe et al.

Table 1. Location of termite sampling at Dramaga Campus of IPB University

\begin{tabular}{|c|c|c|c|}
\hline No & Location codes & Detail of locations & Coordinate \\
\hline \multicolumn{4}{|c|}{ Tree area } \\
\hline 1 & FPI & Rubber experiment garden, Faculty of Fisheries and Marine & $\begin{array}{l}\text { S: } 06^{0} 33.443 \\
\text { E: } 106^{0} 43.579\end{array}$ \\
\hline 2 & $\mathrm{KK}$ & Cocoa experimental garden - Cikabayan & $\begin{array}{l}\text { S: } 06^{0} 33.140^{\prime} \\
\text { E: } 106^{\circ} 43.060^{\prime}\end{array}$ \\
\hline 3 & $\mathrm{KS}$ & Oil palm experiment garden- Cikabayan & $\begin{array}{l}\text { S: } 06^{0} 33.119^{\prime} \\
\text { E: } 106^{0} 43.997\end{array}$ \\
\hline 4 & REK & Rubber experiment field behind the Rectorate of IPB University & $\begin{array}{l}\text { S: } 06^{0} 33.640^{\prime} \\
\text { E: } 106^{0} 43.476\end{array}$ \\
\hline 5 & RES & Sengon tree area & $\begin{array}{l}\text { S: } 06^{0} 33.601 \\
\text { E: } 106^{0} 43.431\end{array}$ \\
\hline \multicolumn{4}{|c|}{ Building area } \\
\hline 6 & AGR & Agrimart, IPB & $\begin{array}{l}\text { S: } 06^{0} 33.566^{\prime} \\
\text { E: } 106^{0} 43.877^{\prime}\end{array}$ \\
\hline 7 & FEM & The parking area Faculty of Economics and Management & $\begin{array}{l}\text { S: } 06^{0} 33.587^{\prime} \\
\text { E: } 106^{0} 43.680^{\prime}\end{array}$ \\
\hline 8 & FEMA & The parking area Faculty of Human Ecology & $\begin{array}{l}\text { S: } 06^{0} 33.587^{\prime} \\
\text { E: } 106^{0} 43.699^{\prime}\end{array}$ \\
\hline 9 & FKH & Backyard Faculty of Veterinary Medicine & $\begin{array}{l}\text { S: } 06^{0} 33.483^{\prime} \\
\text { E: } 106^{0} 43.183^{\prime}\end{array}$ \\
\hline 10 & LSI & The parking area Library of IPB University & $\begin{array}{l}\text { S: } 06^{0} 33.521^{\prime} \\
\text { E: } 106^{0} 43.632\end{array}$ \\
\hline 11 & MA & Al-Hurriyyah Mosque & $\begin{array}{l}\text { S: } 06^{0} 33.343^{\prime} \\
\text { E: } 106^{0} 43.496\end{array}$ \\
\hline 12 & PDI & IPB lecturer housing yards & $\begin{array}{l}\text { S: } 06^{0} 33.229^{\prime} \\
\text { E: } 106^{0} 43.428^{\prime}\end{array}$ \\
\hline 13 & ARL & Arboretrum of Landscape Architecture, IPB & $\begin{array}{l}\text { S: } 06^{0} 33.654^{\prime} \\
\text { E: } 106^{0} 43.726\end{array}$ \\
\hline 14 & FAPET & Animal Husbandry Faculty & $\begin{array}{l}\text { S: } 06^{0} 33.328^{\prime} \\
\text { E: } 106^{0} 43.057\end{array}$ \\
\hline 15 & GLA & Gladiator Yard of IPB University & $\begin{array}{l}\text { S: } 06^{0} 33.602^{\prime}, \\
\text { E: } 106^{0} 43.801\end{array}$ \\
\hline
\end{tabular}


(2008). The variables observed were type of soil, soil $\mathrm{pH}$, cover crop, shade type, and the percentage of shape. The percentage of shade level was measured by observing the canopy that covers the termite observation location. The percentages given were low (0-25\%), moderate (26-50\%), high (51-75\%), and very high (76$100 \%$ ) (Figure 2).
Data Analysis. Observation and calculation of termite species found in the field were analyzed in diversity and abundance index. The diversity index is obtained by using the Shannon-Wiener index (H'), while the abundance index of species is calculated by the Simpson index (D), also index for the number of species (S) and evenness (E).

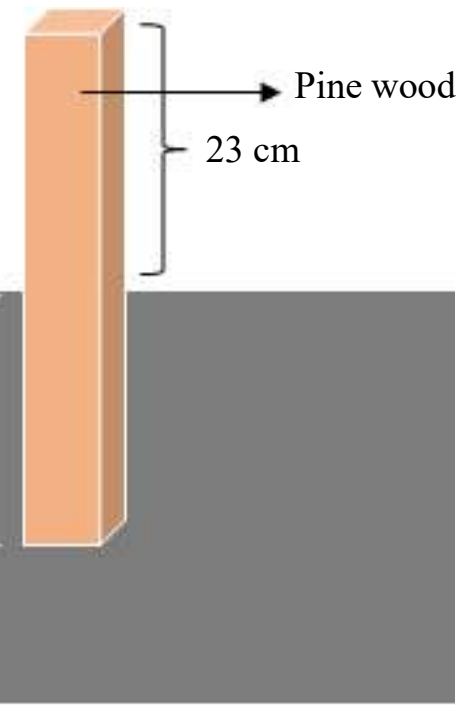

Figure 1. Installation of pine wood bait in the field
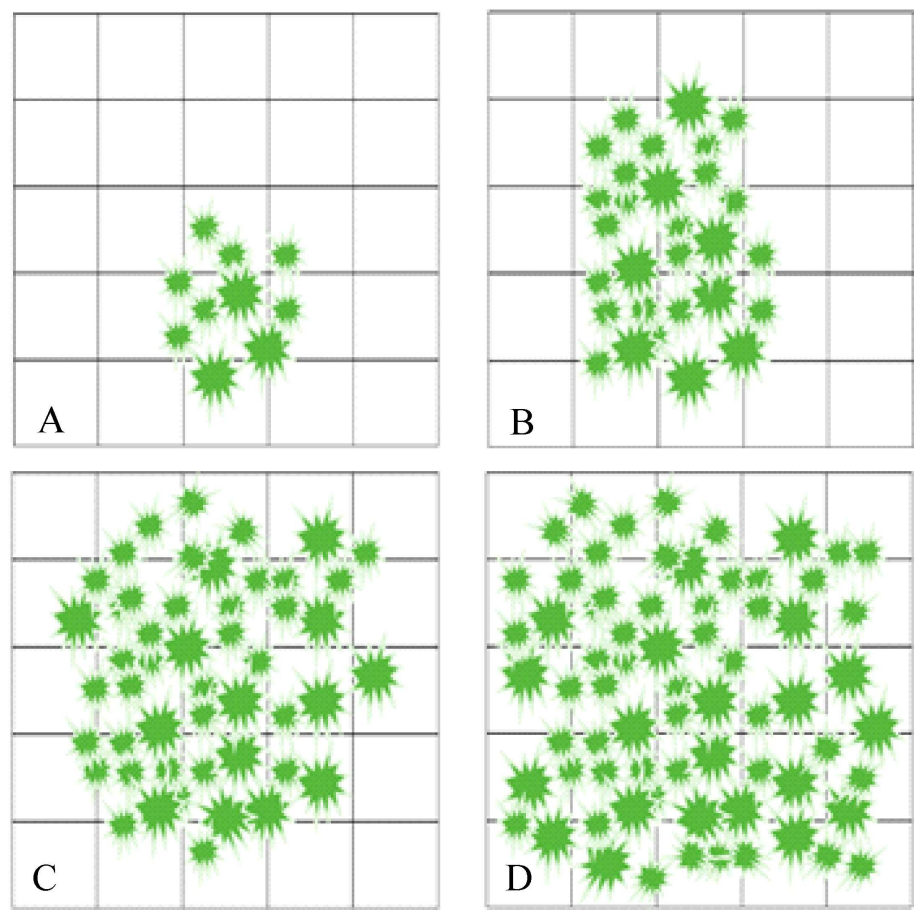

Figure 2. The percentage of shade level; (A) low 0-25\%, (B) moderate 26-50\%, (C) high 51-75\%, (D) very high 76-100\%, 萧: shade by tree. 
The Shannon-Wiener Index $(\mathrm{H})$ can be calculated using the formula:

$$
\mathrm{H}^{\prime}=-\sum_{\mathrm{i}=1}^{\mathrm{n}} \mathrm{Pi} \ln \mathrm{Pi}
$$

$H^{\prime}$ : species diversity index

Pi : proportion of the number of individuals of type-i

(ni) / total number of individuals $(\mathrm{N})$

ni : number of individual type-i

$\mathrm{N}$ : total number of individuals

The criteria used are:

$\mathrm{H}^{\prime}<1.00 \quad$ : low species diversity

$1.00<\mathrm{H}^{\prime}<3.00$ : moderate species diversity

$\mathrm{H}^{\prime}>3.00 \quad$ : high species diversity

The Simpson Index (Ds) can be calculated using a formula:

$$
\frac{1}{\mathrm{Ds}}=\sum(\mathrm{Pi})^{2}=\Sigma\left[\frac{\mathrm{ni}[\mathrm{ni}-1]}{\mathrm{N}[\mathrm{N}-1]}\right]
$$

\section{Ds : Simpson index}

$\mathrm{Pi}$ : proportion of the number of individuals of type-i

(ni) / total number of individuals $(\mathrm{N})$

ni : number of individual type-i

$\mathrm{N}$ : total number of individuals

Simpson index criteria are divided into 3 categories:

$0.01-0.30$ : low complexity

$0.31-0.60$ : moderate complexity

$0.61-1.00$ : high complexity

The species evenness index (E) illustrates the size of the number of individuals between species in a community. The more even distribution of individuals between species, the balance of the ecosystem will increase (Ludwig \& Reynolds, 1988). The formula used to obtain the Evennes index value is:

$$
\mathrm{E}=\frac{\mathrm{H}^{\prime}}{\ln (\mathrm{S})}
$$
E : Evennes index
H' : Shannon-Wienner index
ln : natural logarithm
$\mathrm{S}$ : number of species found

Evennes index criteria are divided into 3 categories: $0<\mathrm{E}<0.3$ : low evenness, depressed community $0.3<\mathrm{E}<0.6$ : moderate evenness, unstable community $0.6<\mathrm{E}<1.0$ : high evenness, stable community

All indicators were tested further by analysis of similarity (ANOSIM), Bray-Curtis similarity index (Magurran, 2003). The results of the matrix are made on non-matrix multidimesional scaling (NMDS) ordination (Clarke, 1993). The analysis was carried out using R-Statistic software (R-Development Core Team, 2013).

\section{RESULTS AND DISCUSSION}

Termite Species Diversity. Identification results obtained six species of termites from two families, Termitidae and Rhinotermitidae. Species from the Termitidae family were Macrotermes gilvus Hagen, Microtermes insperatus Kemner, Capritermes mohri Kemner, and Odontotermes javanicus Holmgren (Figure 3), whereas from the family Rhinotermitidae
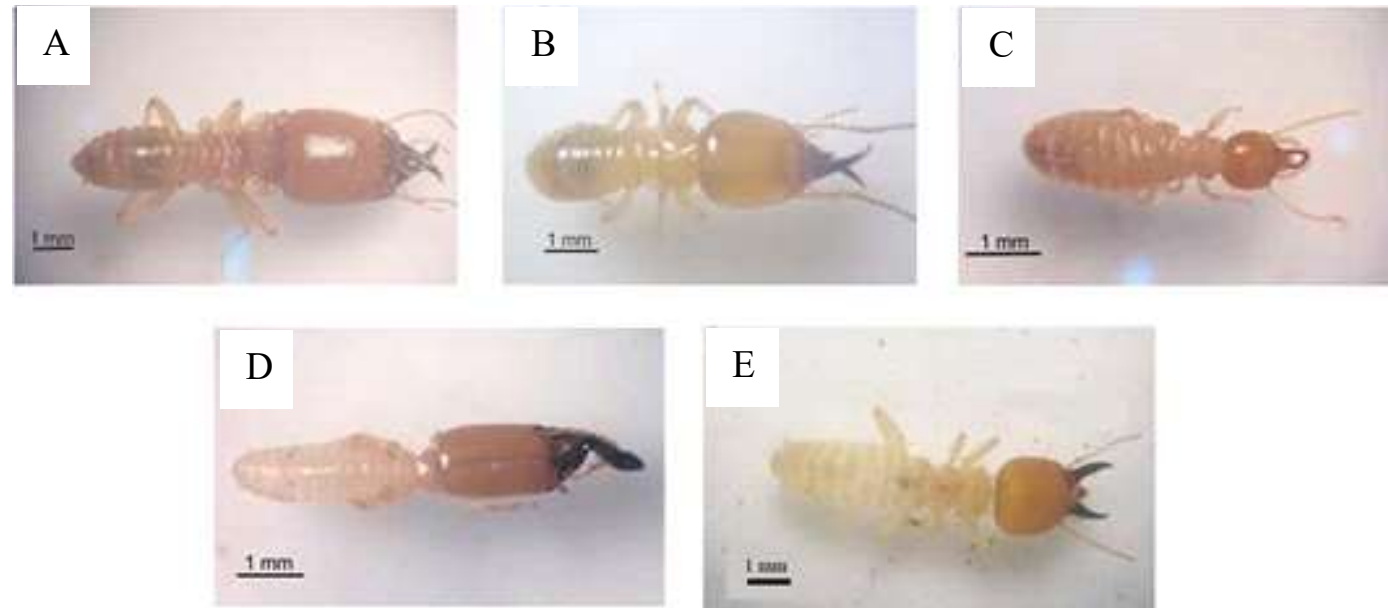

Figure 3. Termites of family Termitidae; (A) M. gilvus (major), (B) M. gilvus (minor), (C) M. insperatus, (D) C. mohri, (E) O. javanicus (magnification 100x). 
were Schedorhinotermes javanicus Kemner and Coptotermes curvignathus Holmgren (Figure 4).

The termite species had a unique characteristic that can ease the initial identification process through their morphology or the odor emitted from the termite colony. Among the six termite species, there were two species that have dimorphism in the soldier caste that were $M$. gilvus and S. javanicus (Figure 3A-B, Figure 4A-B). Both species have different size of soldier caste for major and minor soldier. Major soldier caste was characterized by a larger size than minor soldier caste. Misidentification often occurs when only one caste of soldiers is found, so the sampling process needs to be done thoroughly. The size of the soldier caste in $O$. javanicus had a similar size and shape compared to M. gilvus, so that when found only one M. gilvus minor soldier caste it will be difficult to identify.

The termite species of $C$. mohri and C. curvignathus were unique in defending themselves from their enemies. Mandibles of $C$. mohri were asymmetrical in shape (Figure 3D) compared to other types of termite mandibles. The mandible function of this termites was not used as a means of pinching or capturing enemies, rather as a snapping tool. Termites will be snapping their mandible so that the termites will be thrown up and avoid the enemy (Ahmad, 1958). The C. curvignathus also has a self-defense tool that was whitish liquid coming out of the fontanel in front of the head. The whitish liquid is sticky and will be sprayed when an enemy approaches (Tho, 1992).
Compared to other species, $M$. insperatus has a small body size with a mandible shaped like a crescent moon (Figure 3C). Morphologically, this termite was no different from others, but these termites had a characteristic that is able to emit a distinctive aroma. This species can be recognized easily because of the odor emitted was like jasmine. The odor is a hydrocarbon composition released from the body cuticle. These hydrocarbon compounds can be used as markers of enemy attacks or as sex pheromones (Roomi et al. 1991).

Termites found in the field have unequal numbers of colonies. This shows the abundance of termite species in the field. The number of observed termite species colonies were $M$. insperatus, $O$. javanicus, M. gilvus, $S$. javanicus, $C$. mohri, and $C$. curvignathus as many as $15,14,13,7,5$, and 5 colonies, respectively (Table 2 ). Based on the results obtained, termites belonging to the Termitidae family have a greater number of colonies than the Rhinotermitidae family (47 and 12 colonies, respectively) (Table 2). According to Krishna (1969) and Nandika et al. (2015), termites of the family Termitidae have $1 / 3$ more species of the total termites compared to other termite families such as Rhinotermitidae, Kalotermitidae, Mastotermitidae and others. Termites of the family Termitidae have compatible abilities and able to colonize habitats better than other families.
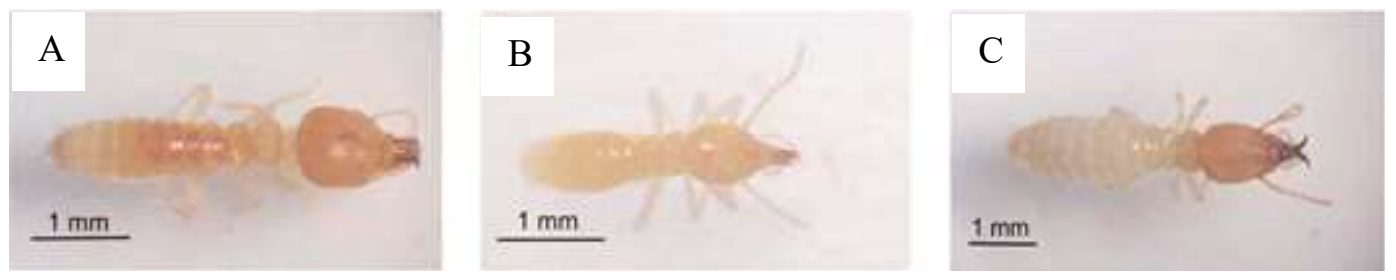

Figure 4. Termites of family Rhinotermitidae (A) S. javanicus (major); (B) S. javanicus (minor); (C) C. curvignathus (magnification 100x).

Table 2. Types and numbers of observed termite species colonies from the field

\begin{tabular}{cllc}
\hline Family & \multicolumn{1}{c}{ Subfamily } & \multicolumn{1}{c}{ Spesies } & Total \\
\hline Termitidae & Macrotermitinae & M. gilvus Hagen & 13 \\
& & M. insperatus Kemner & 15 \\
& & O. javanicus Holmgren & 14 \\
& Termitinae & C. mohri Kemner & 5 \\
Rhinotermitidae & Rhinotermitinae & S. javanicus Kemner & 7 \\
& Coptotermitinae & C. curvignathus Holmgren & 5 \\
\hline
\end{tabular}


Relationships between Termite Species in Various Habitat. Each species of termite has a different behavior. Termite activity is very dependent on the habitat it occupies because the basic behavior of termites is foraging for the needs of the colony. In addition, the existence of termites is also influenced by several things such as soil type, vegetation type, and the percentage of canopy.

Soil Type and pH. The results show that there are two types of soil, regosol and latosol. Regosol type was characterized by black and rough color due to its high porosity (sandy) (Figure 5A). While latosol type was characterized by soft soil and contains a lot of organic material, iron and aluminum, red to yellow so it is often referred to as red soil (Figure 5B).

Termite species indicate that all types of termites (98.31\%) were found in latosol soil types (Figure 6). According to Nandika et al. (2015), generally soil termites are often found nesting in latosol soils because they contain a high organic matter. Coptotermes and other soil termites like the type of soil that contains clay because of the high organic matter to provide better carrying capacity for the colony (Sands, 1969; Majid \& Ahmad, 2013). Termites like shelter from light (cryptobiotic) and underground movements make many termites to build nests in the form of mounds on land that contains a lot of cellulose (Kamble \& Davis, 2005). Meanwhile, only the O. javanicus termites (Figure 7) was found in regosol soils which was generally sandy with a percentage of $1.69 \%$ (Figure 6). Despite of the low organic matter, this termites had the ability to adapt and colonize habitats better than other species.

In addition, the acidity of the tested soil showed that the $\mathrm{pH}$ of the soil ranged below 7 (Table 3). All types of termites were found at acidity level 5, while acidity levels 4 and 6 contained various number of termite species (Table 3). According to Li et al. (2017), the soil acidity in the environment in the nest of $O$. formosanus and around that is at the acidity level 5. Termites prefer the soil with a sufficient acidity level of around 5 because the soil at the acidity level contains a lot of organic matter.
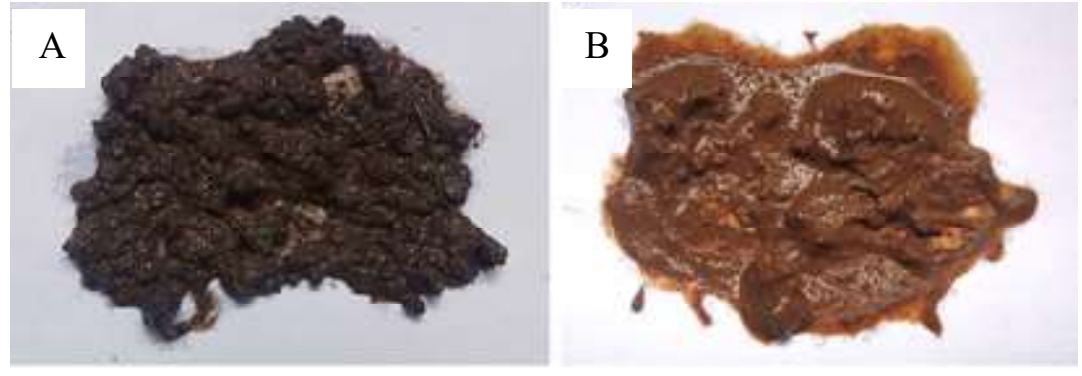

Figure 5. Soil types; (A) Regosol, (B) Latosol.

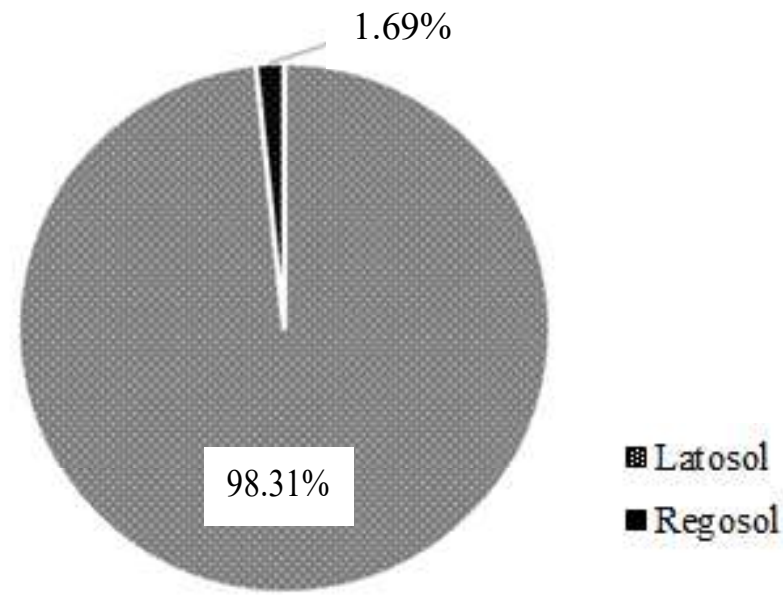

Figure 6. Percentage of termite colonies in latosol and regosol soils. 
Land Cover Vegetation. The land cover vegetation at termite sampling locations were obtained mostly from weed species. Weeds that become vegetation cover also become a barrier so that the soil texture is not reduced to homogeneous. Soil vegetation also functions to reduce surface runoff due to rain (Lamaourex \& O'Kane, 2012). The land cover system will benefit from the behavior of termites, that will increase the moisture and physical stability of the soil. Subterranean termites prefer ideal habitat conditions with stable temperature and humidity when compared to open land conditions with extreme microclimates that will affect surrounding microhabitat (Sands, 1969).

Land cover vegetation found were Axonopus compressus, Asystasia gangetica, Setaria plicata, Centotheca lappacea, Cyclosorus aridus, Digitaria adscendens, and Panicum repens. On the land covered by $A$. compressus, $C$. lappacea, and $C$. aridus, all termite species were observed. Whereas, in P. repens, only $O$. javanicus were observed (Table 4).

Table 3. Distribution of termite species at various levels of soil acidity

\begin{tabular}{lccc}
\hline & \multicolumn{3}{c}{ Soil pH } \\
\cline { 2 - 4 } Termites & 4 & 5 & 6 \\
\hline M. gilvus & $\mathrm{v}$ & $\mathrm{v}$ & $\mathrm{v}$ \\
M. insperatus & $\mathrm{v}$ & $\mathrm{v}$ & $\mathrm{v}$ \\
O. javanicus & $\mathrm{v}$ & $\mathrm{V}$ & $\mathrm{v}$ \\
C. mohri & $\mathrm{v}$ & $\mathrm{v}$ & - \\
S. javanicus & - & $\mathrm{v}$ & - \\
C. curvignathus & - & $\mathrm{v}$ & - \\
\hline
\end{tabular}

Table 4. Relationships of land cover plants and termite species

\begin{tabular}{lcccccc}
\hline \multirow{2}{*}{ Weed } & \multicolumn{5}{c}{ Termites species } \\
\cline { 2 - 7 } & M. gilvus & M. insperatus & O. javanicus & C. mohri & S. javanicus & C. curvignathus \\
\hline A. compressus & $\sqrt{ }$ & $\sqrt{ }$ & $\sqrt{ }$ & $\sqrt{ }$ & $\sqrt{ }$ & $\sqrt{ }$ \\
A. gangetica & - & $\sqrt{ }$ & $\sqrt{ }$ & - & - & - \\
S. plicata & $\sqrt{ }$ & $\sqrt{ }$ & $\sqrt{ }$ & - & - & - \\
C. lappacea & $\sqrt{ }$ & $\sqrt{ }$ & $\sqrt{ }$ & $\sqrt{ }$ & $\sqrt{ }$ & $\sqrt{ }$ \\
C. aridus & $\sqrt{ }$ & $\sqrt{ }$ & $\sqrt{ }$ & $\sqrt{ }$ & $\sqrt{ }$ & - \\
D. adscendens & - & $\sqrt{ }$ & - & - & - & - \\
P. repens & - & - & $\sqrt{ }$ & - & - & - \\
\hline
\end{tabular}

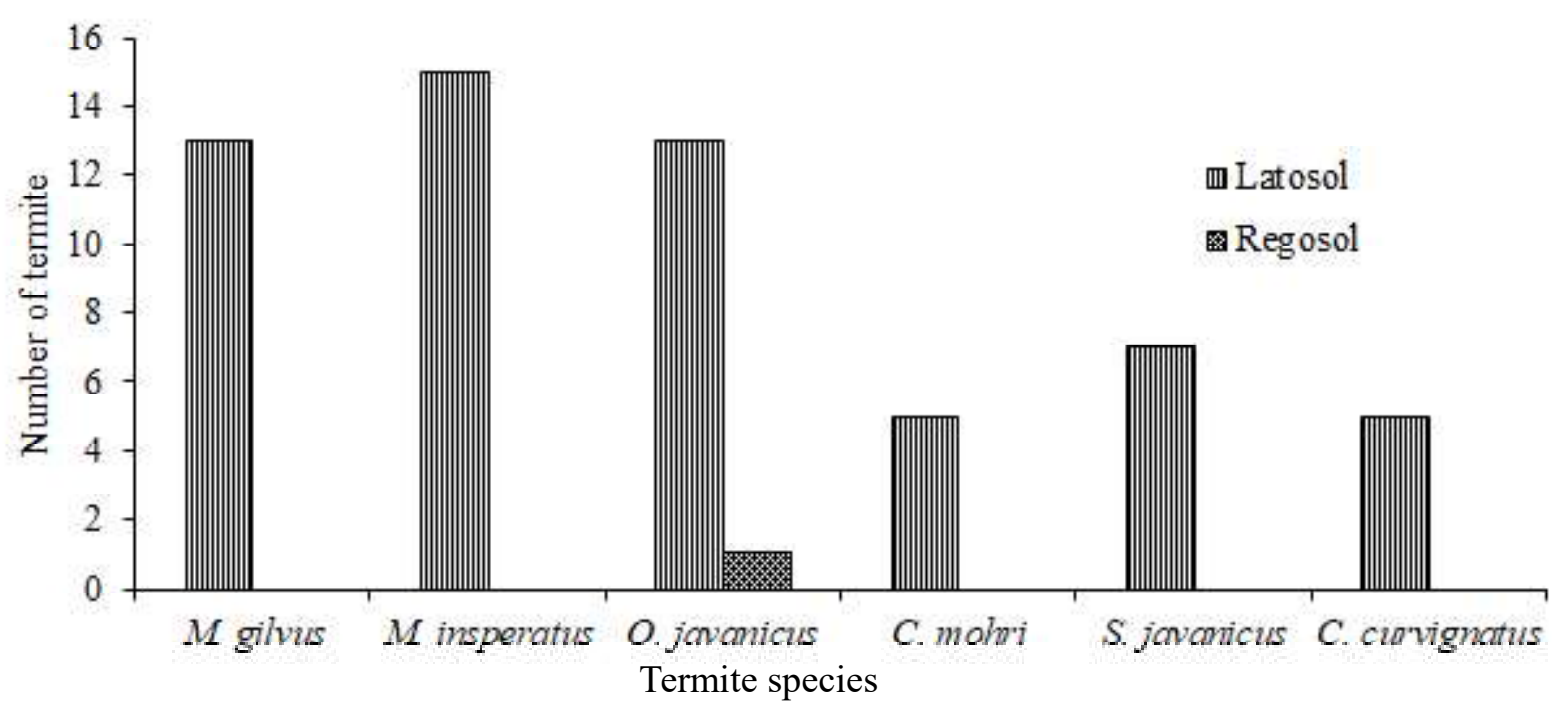

Figure 7. Number of termite species found in latosol and regosol soil types. 
Land covered by $A$. compressus, C. lappacea, and $C$. aridus have a very rapid rate of colonizing and breeding due to climate in research location which tends to have a high rainfall intensity around $301 \mathrm{~mm}(\mathrm{BMKG}$, 2013). In addition, the three types of land cover crop can grow in a partially or completely shaded area. Whereas $P$. repens land cover crop that have a high stature tend to live in areas with direct or no sun shade exposure.

Shade Percentage. The higher the level of shade, the more number of termite colonies discovered. Generally, the number of termite colonies in the low shade level $(0-25 \%)$ was small. However, in this area high number of $O$. javanicus colonies were observed (Figure 8). It was suspected that $O$. javanicus had better ability to colonize habitats at low level of shade. In contrast to the other termite species, the amount found was relatively small at a low level of shade.

At a moderate level of shade (26-50\%) only four termite species colonies were found and have different numbers in each termite species. Percentage of high shade levels (51-75\%) and very high shade (76-100\%) were found in six species of termites. Locations with high and very high levels of shade differ only in the number of termite colonies found. At high shade levels, the number of termite colonies found was relatively same. Unlike the case with very high levels of shade, the termites of $M$. gilvus and M. insperatus were found to be more numerous than other species (Figure 8). It was suspected that $M$. gilvus and $M$. insperatus more favored at very high levels of shade, while other termite species tend to be intolerant. Most of the termites species was found in a high level of shade (51-75\%) because termites needs sunlight for the habitat (Sands, 1969).

The percentage of shade have an effect on the number of colonies and the number of termites species. The higher shade, the more diverse of termites were found. This was due to the high level of shade which has a relatively stable microclimate so that it was preferred by termites. A stable microclimate will increase soil microfauna which will support termite life (Sands, 1969).

The level of disturbance based on the intensity of human activity in the habitat. This will provide a significant influence on the number of organisms that live and breed in it. More intensive use of land types by humans, the land will be more disturbed. Areas or land with high gaps due to land management, causing land to be more open. A wide gap will cause direct sunlight to illuminate the land without any obstructions. This causes the land to be increasingly disturbed and the number of termite colonies that are nested and which makes the path of the tunnel was less. However, different with types of termites Hospitalitermes hospitalis who generally do not make a wandering path in their foraging behavior. Although it does not have a wandering

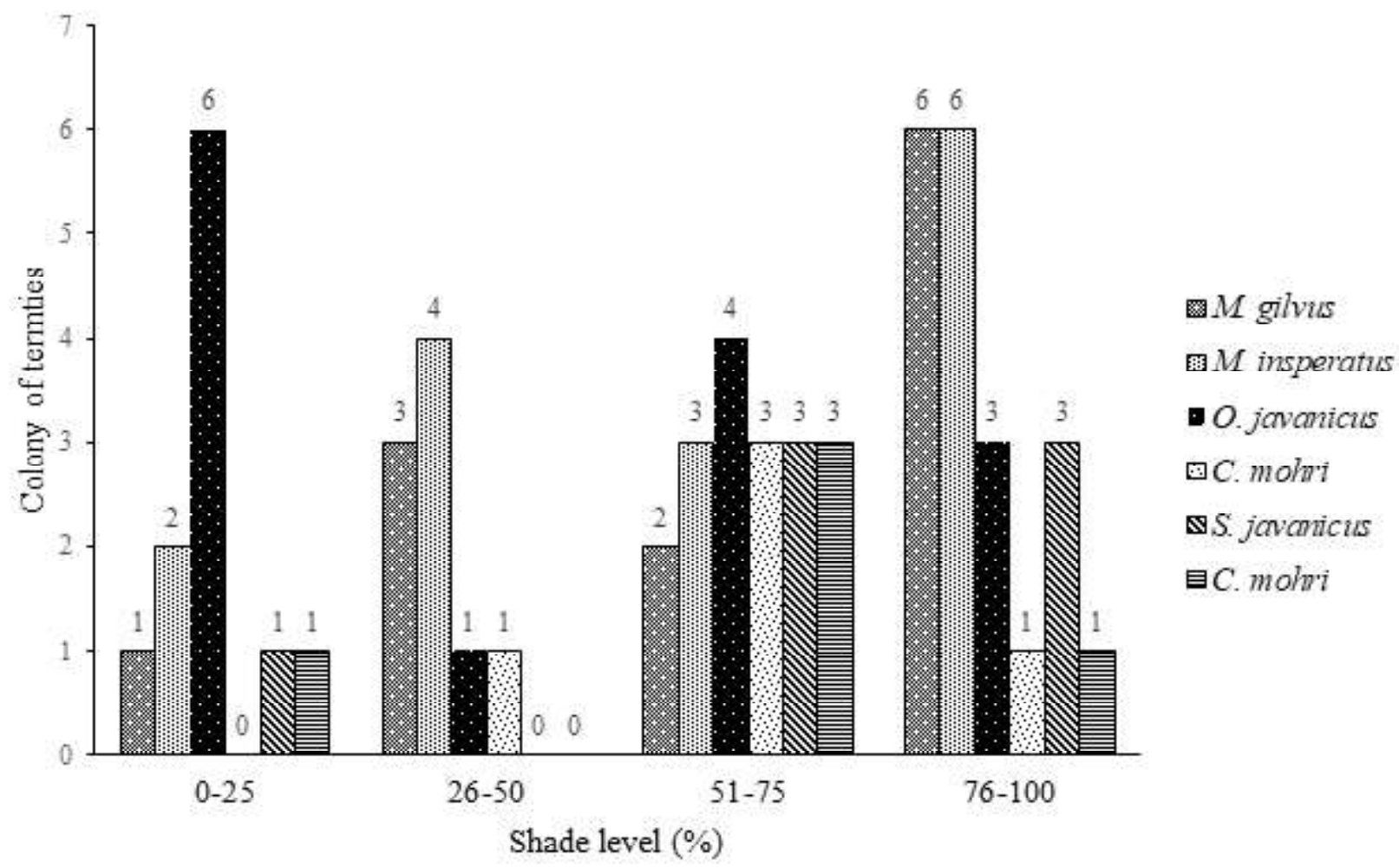

Figure 8. Relationship between the percentage of shade level and the number of termites found 
pathway, its foraging behavior is the same as other termites that cannot be directly exposed to sunlight so that these types of termites forage at night to avoid dehydration in their bodies (Jones \& Hardy, 1995).

Conversely, the more closed a land (such as a forest area) that was difficult to be penetrated by sunlight and without the processing of land, the more termites were found (Keng, 2006). In Figure 8 shows that the level of shade with high and very high criteria $(51-100 \%)$ had an influence on the number of colonies found. The number of termite colonies that found on these criteria will be higher.

Index of Diversity and Abundance of Termite Species. The highest Shannon-Wiener $(\mathrm{H})$ diversity index and Simpson (D) abundance were 1.72 and 0.80 respectively in the type of tree area i.e. the rubber plantation behind the main administration building (REK). While the lowest index values were in building type areas such as Agrimart (AGR), Faculty of Economics and Management area (FEM), cocoa farms (KK), Al Hurriyah Mosque (MA), IPB lecturer housing yards (PDI), and sengon tree area (RES) with the number 0 for both indexes (Table 5). This shows that the rubber trees area in IPB (REK) had a high diversity and abundance compared to building areas such as the Agrimart building area (AGR), the Faculty of Economics and Management Building (FEM), and so on. The area of rubber trees was a shady area and filled with cellulose sources such as twigs, leaves, and rubber wood causing high termite diversity and abundance. Compared to other areas that tend to have few shade trees and are dominated by buildings so that there were not many sources of cellulose in the vicinity.

In the index the number of species (S) had a similarity to the region both having the highest or lowest value with the species evenness index $(\mathrm{E})$. The highest values in the index of species and evenness were 6 and 0.83 in the rubber trees area in the Faculty of Fisheries (FPI) and behind the main administration building (REK) respectively, while the lowest number is 1 and $\mathrm{NaN}$ (not listed) in the building area, namely the Agrimart area (AGR), the Faculty of Economics and Management (FEM) area, cocoa gardens (KK), Al Hurriyah Mosque (MA), IPB lecturer housing area (PDI), and sengon tree area (RES) (Table 5). From the number of species and evenness of species index shows that the rubber trees area in the Faculty of Fisheries and behind the main administration building had a high value because these areas have abundant sources of organic material as food for termites, compared to other areas with buildings that tend to always be cleaned so that the index the number of species was low. Even though the area of cocoa plantation (KK) and sengon tree area (RES) which generally have a lot of food sources (leaves, twigs, and weathered stems) but have a low index value because these areas become areas of practice and testing that were often cleared for educational purposes at IPB University.

For the number of species and species evenness (E) indices, the greater the number obtained at the index, the level of evenness in the habitat is higher and the community within it was stable. Vice versa, the smaller the number obtained, the level of evenness of the habitat was low and the community in the habitat was unstable and even depressed.

\section{Structure of Termite Composition in Different} Habitat Types. Analysis of similarity show that different habitat types on IPB University campus affect termite diversity $(\mathrm{R}=0.3873, \mathrm{P}=0.011)$. Different types of habitats have different termite diversity significantly which indicated by the separation between habitats.

The incision between the backyard area of the Faculty of Veterinary Medicine (FKH), the arboretrum of Landscape Architecture (ARL), and the palm oil plantation (KS) has similarities in the composition of termite species (Figure 9). The farther the plot point shows the lower the level of dissimilarity. For example, the cocoa plantation area (KK) and the enclosure of the Faculty of Animal Husbandry (FAPET) show the dissimilarity of existing species. This was because in the cocoa plantation area $(\mathrm{KK})$ only one termite species was found with a total of 4 colonies, whereas in the enclosure of the Faculty of Animal Husbandry (FAPET) only 3 colonies were found, but had different species (Figure 9).From the ANOVA results, the abundance of termites in the building area and in the tree area of the Campus of IPB University has a very significant difference with the P-value obtained which is 0.000831 which means less than 0.05 or even 0.01 (Table 5). These show that the composition of termites in the area of trees found was greater than in the building area. This was due to the fact that there were abundant sources of cellulose for termite food compared to building areas that tend to always be cleaned because it was close to human activities such as the Agrimart building (AGR), the Faculty of Economics and Management (FEM) building so that the cellulose source was used as termite's food was not always available. 


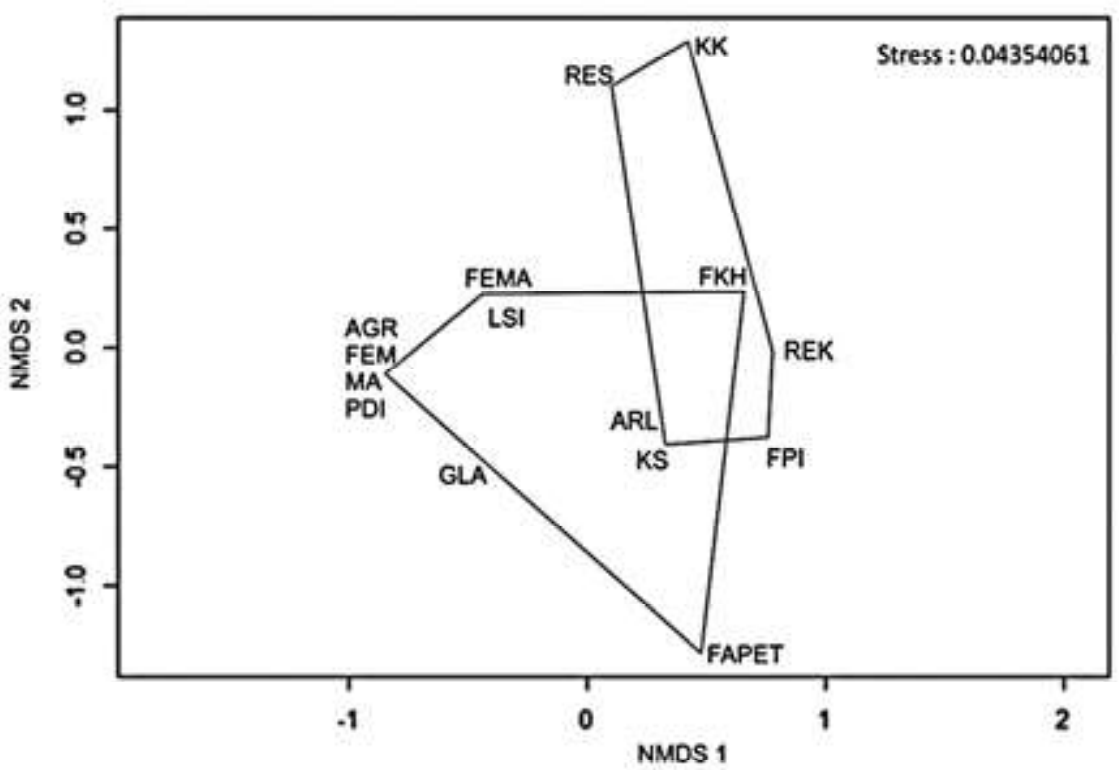

Figure 9. NMDS of termite composition based on Bray-Curtis dissimilarity index at Campus IPB

Table 5. Composition of H, D, S, and $\mathrm{E}$ index of communities in various habitats in IPB

\begin{tabular}{ccccc}
\hline & \multicolumn{3}{c}{ Index } & \\
\cline { 2 - 5 } Habitat & $\mathrm{H}$ & $\mathrm{D}$ & $\mathrm{S}$ & $\mathrm{E}$ \\
\hline AGR & 0.00 & 0.00 & 1 & $\mathrm{NaN}$ \\
ARL & 1.56 & 0.77 & 5 & 0.96 \\
FAPET & 1.09 & 0.66 & 3 & 1.00 \\
FEM & 0.00 & 0.00 & 1 & $\mathrm{NaN}$ \\
FEMA & 0.69 & 0.50 & 2 & 1.00 \\
FKH & 1.27 & 0.69 & 4 & 0.92 \\
FPI & 1.49 & 0.70 & 6 & 0.83 \\
GLA & 0.69 & 0.50 & 2 & 1.00 \\
KK & 0.00 & 0.00 & 1 & $\mathrm{NaN}$ \\
KS & 1.32 & 0.72 & 4 & 0.95 \\
LSI & 0.69 & 0.50 & 2 & 1.00 \\
MA & 0.00 & 0.00 & 1 & $\mathrm{NaN}$ \\
PDI & 0.00 & 0.00 & 1 & $\mathrm{NaN}$ \\
REK & 1.72 & 0.80 & 6 & 0.96 \\
RES & 0.00 & 0.00 & 1 & $\mathrm{NaN}$ \\
\hline
\end{tabular}

Habitat location code is the same as table 1.

\section{CONCLUSION}

Six species of termites were found including $M$. gilvus, O. javanicus, M. insperatus, and C. mohri (Termitidae family), S. javanicus and C. curvignathus (Rhinotermitidae family). The highest diversity and abundance of termites were found in rubber trees area,
Faculty of Fisheries (FPI) and behind the main administration building (REK) because these areas have abundant cellulose sources as food sources for termite. Meanwhile, the building area tends to have a lower diversity and abundance index because the food sources from termites were not always available due to human activities. 


\section{ACKNOWLEDGMENT}

Authors thank Mr. Suhata from DHH IPB for his assistance during pine sticks making process, Mrs. Arinana for the discussions related to this field research, Ratna Rubiana for the help in data processing, and Ihsan Nurkomar for help to check the language.

\section{REFERENCES}

Ahmad M. 1958. Key to the Indomalayan Termites. University of Panjab, Pakistan.

Arinana, Aldina R, Nandika D, Rauf A, Harahap IS, Sumertajaya IM, \& Bahtiar ET. 2016. Termite diversity in urban landscape, South Jakarta, Indonesia. Insects. 7(20): 1-18.

Arinana, Haneda NF, Nandika D, \& Prawitasari WA. 2014. Damage intensity of house building and termite diversity in Perumahan Nasional Bumi Bekasi Baru, Rawalumbu Bekasi. In: Hartono R, Iswanto AH, Hartini KS, Susilowati A, Elfiati D, Muhdi, Zahra M, Latifah S, Batubata R, Anna N, Sucipto T, \& Azhar I (Eds.). Proceeding the $6^{\text {th }}$ International Symposium of Indonesian Wood Research Society. pp. 134-142. Indonesian Wood Researc Society (IWoRS), Medan.

ASTM. 2008. Standard Test Method of Evaluating Wood Preservatives by Field Test with Stakes. ASTM D 1758-08. American Society for Testing and Material, United States of America, Washington, DC.

BMKG. 2013. Analisis Iklim. BMKG, Indonesia.

Bignell DE \& Eggleton P. 2000. Termites in ecosystems. In: Abe T, Bignell DE, \& Higashi M (Eds.). Termites: Evolution, Sociality, Symbioses, Ecology. pp. 363-387. Springer Dordrecht, Netherlands.

Bong JCF, King PJH, Ong KH, \& Mahadi NM. 2012. Termites assemblage in oil palm plantation in Sarawak, Malaysia. J. Entomol. 9(2): 68-78.

Clarke KR. 1993. Non-parametric multivariate analyses of change in community structure. Aust. J. Ecol. 18(1): 117-143.

Deblauwe I, Dibog L, Missoup AD, Dupain J, Elsacker VE, Dekoninck W, Bonte D, \& Hendrickx F. 2008. Spatial scales affecting termite diversity in tropical lowland rainforest: a case study in southeast Cameroon. Afr. J. Ecol. 46(1): 5-18.
Freymann BP, Buitenwerf R, Desouza OG, \& Olff H. 2008. The importance of termites (Isoptera) for the recycling of herbivore dung in tropical ecosystems: a review. Eur. J. Entomol. 105(2): $165-173$.

Haneda NF, Retmadhona IY, Nandika D, \& Arinana. 2017. Biodiversity of subterranean termites on the Acasia crassicarpa plantation. Biodiversitas. 18(4): 1657-1662.

Jasmi AH \& Ahmad AH. 2011. Termite incidence on an Araucaria plantation forest in Teluk Bahang, Penang. Insects. 2(4): 469-474.

Jones DT. 2000. Termite assemblages in two distinct montane forest types at $1000 \mathrm{~m}$ elevation in the Maliau Basin, Sabah. J. Trop. Ecol. 16(2): 271286.

Jones DT \& Gathorne-Hardy F. 1995. Foraging activity of the processional termite Hospitalitermes hospitalis (Termitidae: Nasutitermitinae) in the rain forest of Brunei, north-west Borneo. Insectes Soc. 42(4): 359-369.

Jones DT, Susilo FX, Bignell DE, Hardiwinoto S, Gillison AN, \& Eggleton P. 2003. Termite assemblage collapse along a Land-use intensification gradient in lowland central Sumatra, Indonesia. J. Appl. Ecol. 40: 380-391.

Kamble ST \& Davis RW. 2005. Innovation in perimeter treatement against subterranean termites (Isoptera: Rhinotermitidae). In: Lee CY \& Robinson WH (Eds.). Proceedings of the Fifth International Conference on Urban Pests. pp. 197-203. P\&Y Design Network, Malaysia.

Keng WM. 2006. Species comparison of termites (Isoptera) in primary forest of Tawau Hills Park, Sabah and adjacent cocoa plantation area. Thesis. University Malaysia Sabah, Sabah.

Krishna K. 1969. Introduction. In: Krishna K \& Weesner FM (Eds.). Biology of Termites. pp. 1-17. Academic Press Inc., New York and London.

Lamoureux S \& O'Kane M. 2012. Effects of termites on soil cover system performance. In: Fourie AB \& Tibbett M (Eds). Conference Seventh International Conference on Mine Closure. pp. 432-446. Australian Centre for Geomechanics, Perth. 
Lantera KG. 2014. Keragaman spesies rayap tanah di Jakarta Barat dan Jakarta Timur. Skripsi. Institut Pertanian Bogor, Bogor.

Li Y, Dong ZY, Pan DZ, Pan CH, \& Chen LH. 2017. Effect of termite on soil $\mathrm{pH}$ and its application for termite control in Zhejiang Province, China. Sociobiology. 64(3): 317-326.

Ludwig JA \& JF Reynolds. 1988. Statistical Ecology: a Primer on Methods and Computing. John Wiley \& Sons, New York.

Magurran AE. 2003. Ecological Diversity and Its Measurement. Springer, Dordrecht.

Majid AHA \& Ahmad AH. 2013. Termites infestation associated with type of soil in Pulau Pinang, Malaysia (Isoptera: Rhinotermitidae). Trop. Life Sci. Res. 24(2): 91-95.

Nandika D, Rismayadi Y, \& Diba F. 2015. Rayap: Biologi dan Pengendaliannya. Muhammadiyah University Press, Surakarta.

Paul B, Khan MdA, Paul S, Shankarganesh K, \& Chakravorty S. 2018. Termites and indian agriculture. In: Khan MdA \& Ahmad W (Eds.). Termites and Sustainable Management Volume 2-Economic Losses and Management. pp. 5196. Springer International Publishing, Cham.
R-Development Core Team. 2013. $R$ : A language and environment for statistical computing [internet]. Vienna: R Foundation for Statistical Computing. Accessed on: http://cran.r-project.org/

Roomi MW, Shah AH, \& Anwarullah M. 1991. Sex pheromone of Microtermes obesi holmgren isoptera termitidae. Sarhad J. Agric. 7(6): 761764

Sands WA. 1969. The association of termites and fungi. In: Krishna K \& Weesner FM (Eds.). Biology of Termites. pp. 495-524. Academic Press Inc., New York and London.

Tho YP. 1992. Termites of Peninsular Malaysia. Forest Research Institute Malaysia, Selangor. 